\title{
Original Paper \\ Influence of macronutrients, sucrose and LED on in vitro culture of Lomatozona artemisiifolia (Asteraceae - Eupatorieae)
}

\author{
Livia Cristina da Silva $^{1,3,6}$, Marlene Pires Moreira ${ }^{1,4}$, Andreia Alves da Costa Silveira ${ }^{1,5}$ \& Sérgio Tadeu Sibov ${ }^{2}$
}

\begin{abstract}
Balanced levels of macronutrients and sucrose may ensure the success of micropropagation of the endangered ones. This study aimed to evaluate the effect of levels of salts in the culture medium on in vitro culture of Lomatozona artemisiifolia, as well as to determine the influence of light emitting diode (LED) on the shoot proliferation and rooting of the species. Nodal segments were used to evaluate the different macronutrient concentrations of MS medium (25, 50 and $100 \%)$, as well as sucrose concentrations $(0.0 \mathrm{mM} ; 0.34 \mathrm{mM}$; $0.68 \mathrm{mM}$ and $1.03 \mathrm{mM}$ ). Five light conditions were evaluated at shoots proliferation and rooting [100\% blue $(455 \mathrm{~nm}) ; 100 \%$ red $(630 \mathrm{~nm}) ; 30 \%$ blue $+70 \%$ red; $30 \%$ red $+70 \%$ blue or fluorescent white]. Low levels of macronutrients in MS (50\% and 25\%) and sucrose $(0.00 \mathrm{mM}$ and $0.34 \mathrm{mM})$ resulted in plants with higher height, number of shoots and higher production of photosynthetic pigments. The $100 \%$ red light promoted rooting of $100 \%$ of the plants, and in $100 \%$ red or $70 \%$ red $+30 \%$ blue, higher plants were observed. These results demonstrate that under in vitro conditions, L. artemisiifolia has low nutritional needs, typical of plants that live in rupestrian fields.
\end{abstract}

Key words: culture medium, micropropagation, rock plants, spectral light, sucrose concentration.

\section{Resumo}

Níveis balanceados de macronutrientes e sacarose podem garantir o sucesso na micropropagação de espécies em perigo de extinção. Este estudo teve como objetivo avaliar o efeito de níveis de sais no meio de cultura no cultivo in vitro de Lomatozona artemisiifolia, além de determinar a influência de diodos emissores de luz (LED) na proliferação de brotos e enraizamento da espécie. Segmentos nodais foram utilizados para avaliar as diferentes concentrações de macronutrientes do meio MS (25, 50 e 100\%), bem como de concentrações de sacarose (0,0 mM; 0,34 mM; 0,68 mM e 1,03 mM). Cinco condições luminosas foram avaliadas na proliferação de brotos e enraizamento [100\% azul (455 nm), 100\% vermelho (630 nm), 30\% azul $+70 \%$ vermelho, 30\% vermelho $+70 \%$ azul ou branco fluorescente]. Baixos níveis de macronutrientes no meio MS (50\% e $25 \%$ ) e sacarose $(0,00 \mathrm{mM}$ e $0,34 \mathrm{mM})$ resultaram plantas com maior altura, número de brotos e número de folhas, além de maior produção de pigmentos fotossintéticos. Observou-se que $100 \%$ de luz vermelha promoveu enraizamento de $100 \%$ das plantas, e em $100 \%$ vermelho ou $70 \%$ vermelho $+30 \%$ azul, observou-se médias mais elevadas em altura de plantas. Esses resultados demonstram que, em condições in vitro, L. artemisiifolia apresenta baixas necessidades nutricionais, típicas de plantas que vivem em campos rupestres.

Palavras-chave: meio de cultura, micropropagação, plantas rupestres, espectros de luz, concentração de sacarose.

\footnotetext{
${ }^{1}$ Universidade Federal de Goiás, Escola de Agronomia, Av. Esperança s/n, Campus Samambaia, 74690-900, Goiânia, GO, Brazil..

${ }^{2}$ Universidade Federal de Goiás, Inst. Ciências Biológicas, Depto. Genética, Av. Esperança s/n, Campus Samambaia, 74690-900, Goiânia, GO, Brazil.. ORCID: $<$ https://orcid.org/0000-0001-6404-8271>.

${ }^{3}$ ORCID: <https://orcid.org/ 0000-0001-7683-9759>.

${ }^{4}$ ORCID: <https://orcid.org/0000-0001-8754-2918>.

${ }^{5}$ ORCID: $<$ https://orcid.org/0000-0001-8562-846X>.

${ }^{6}$ Author for correspondence: liviacristy@gmail.com
} 


\section{Introduction}

The Cerrado domain has faced the degradation of its plant resources in several ways (Brandão et al. 2017). Currently, the list of endangered species in this domain is significant due to the constant deforestation (Nakajima et al. 2012), to the competition among invasive species with native species and incorrect management of fire clearing intensifies burning. In addition, it may often decrease the productive capacity of an ecosystem (Martinelli et al. 2014), therefore, giving rise to a threat to the biodiversity of species, especially endangered species, which may disappear.

Lomatozona artemisiifolia Baker is described as an endangered species (Martinelli \& Moraes 2013). This plant has probable medicinal potential with insecticidal action (Moreira 2018), due to the large amount of trichomes, which may indicates the secretion of metabolites (Trindade et al. 2014). The species is characterized as a subshrub ( 30 to $60 \mathrm{~cm}$ ), which is traditionally propagated by seeds, which have a low germination rate $(20-50 \%)$ (Moreira 2018). The occurrence is restricted to the state of Goiás (Brazil), recorded only in the regions of Serranópolis, Mossâmedes and Jataí (Nakajima et al. 2012). This Asteraceae usually grows in regions of rupestrian Cerrado (CNCFlora 2012), which does not have many information records (Nakajima et al. 2012).

The Cerrado is the Brazilian phytogeographic domain that concentrates the largest number of Asteraceae endangered species (Nakajima et al. 2012), in addition to this domain having a large number of rock species from this family (Almeida et al. 2014). Because the Cerrado has been subjected to intense pressures in recent years regarding its deforestation (Brandão et al. 2017), large-scale propagation studies of the species are necessary. Tissue culture has useful methods for large-scale plant propagation. With this set of techniques, it is possible to obtain plantlets much faster than in conventional propagation (Butt et al. 2015). Studies on micropropagation of several species of the Asteraceae family have been developed (Abraham \& Thomas 2018), such as Artemisia lacinata Willd. (an endangered species) (Kodym et al. 2018); Calendula marítima Guss. (a rock plant) (Angela et al. 2016) and Saussurea lappa (Decne.) Sch.Bip. (an endangered and medicinal plant) (Nisa 2018). However, few studies cover nutritional characteristics of the culture medium for rock species (Oliveira et al. 2015).
Several factors may influence in vitro shoot proliferation, such as culture medium components (Faria et al. 2004), light wavelength (Massa et al. 2008), temperature (Pereira-Netto 2001), among others (Espinosa-Leal et al. 2018). In addition, balanced levels of sucrose may interfere with the morphogenesis process. This carbohydrate is largely used in tissue culture as a carbon source to provide energy for explants (Paiva Neto \& Otoni 2003), however, their optimal levels may differ from one species to another (Faria et al. 2004; Sorace et al. 2008). Therefore, balanced levels of sucrose in in vitro cultivation may promote an increase in shoots as well as in number of leaves and pigment content (Faria et al. 2004), which enhances the quality of the produced plantlets. Balanced levels of MS culture medium macronutrient concentrations (Murashige $\&$ Skoog 1962) may also determine the success in micropropagation (Terrer \& Tomás 2001), given that different species have their own nutritional requirements.

Light Emitting Diode (LED) have also been used in tissue culture to improve plantlet quality, as well as accelerate plant growth and improve rooting, which may be reflected in the high survival of plantlets in the acclimatization (Massaro et al. 2018). LED light can act similarly to plant growth regulators (PGR) (Folta \& Childers 2008). Thus, it is may be used both to shoot proliferation (Massa et al. 2008) and to rooting in vitro (Folta \& Childers 2008) through the modulation between light and phytochromes and cryptochromes (Briggs \& Olney 2001).

These advantages are due to the fact that LED lights are considered PAR (Photosynthetically Active Radiation) lights (Gupta \& Jatothu 2013), which guarantee photosynthetic efficiency. This process reflects in photo-morphogenesis which promotes desirable characteristics in the produced plantlets (Stutte 2009; Yeh \& Chung 2009; Silva et al. 2016).

Thus, by considering the increasing deforestation in the Cerrado domain and the fact that $L$. artemisiifolia is an endangered species, in vitro multiplication protocols become necessary for this species. Therefore, the objective of this work was to develop a $L$. artemisiifolia micropropagation protocol by evaluating the influence of different sucrose and macronutrient concentrations in the medium, as well as the influence of different spectral light (LED) on the shoots proliferation and rooting, aiming further studies of acclimatization and population reinforcement with the plantlets produced. 


\section{Material and Methods}

\section{Collection of plant material}

The experiments were performed at the Plant Tissue Culture Laboratory (LabCulTive) of the Universidade Federal de Goiás (UFG), in Goiânia, state of Goias, Brazil. The determination of the botanical material was performed and the registration exsiccate with registration no. 4253 is deposited in the Herbarium of UFG. Seeds were collected in the "Professor José Ângelo Rizzo" Biological reserve, Parque Estadual da Serra Dourada, Mossâmedes, state of Goiás in July, 2017. The seeds were placed in paper bags in glass jars at room temperature $\left(25^{\circ} \mathrm{C} \pm 2\right)$.

\section{In vitro establishment}

Two hundred Lomatozona artemisiifolia seeds (from 3 plant matrices) were placed in a nylon sachet-like package $(5 \times 7 \mathrm{~cm})$. These seeds were placed in an autoclaved bottle together with 20 drops of neutral detergent, and washed in running water for $20 \mathrm{~min}$. After that, asepsis was done with immersion in $70 \%$ alcohol solution for one minute, followed by immersion in sodium hypochlorite $(2.5 \%$ active chlorine) for $10 \mathrm{~min}$. Under aseptic conditions, the seeds were triple washed in autoclaved and distilled water and inoculated into $200 \mathrm{~mL}$ glass flasks containing $30 \mathrm{~mL}$ MS medium (Murashige \& Skoog 1962) with half the macronutrient concentration supplemented with $0.7 \%$ agar (w/v), and $1.03 \mathrm{mM}$ sucrose.

A natural ventilation system was used, with $0.8 \mathrm{~mm}$ opening polypropylene cap, covered with two layers of $0.45 \mu \mathrm{m}$ micro-porous tape (Micropore Cremer AVS-0.45 air vent) and one layer of polytetrafluoroethylene (PTFE) tape between them (Saldanha et al. 2012). After closure of the flasks, they were sealed with three layers of PVC film.

The flasks containing the explants were kept in a growth room at $25 \pm 2{ }^{\circ} \mathrm{C}$, and photoperiod of 16 hours of light and 8 hours of dark with fluorescent white light under $25 \mu \mathrm{mol} . \mathrm{m}^{-2} . \mathrm{s}^{-1}$ irradiance. After 15 days, plantlets with two complete leaf pairs were transferred to flasks with MS medium. After 60 days, the 200 plantlets were assigned to the shoot proliferation experiments.

\section{Influence of different macronutrient} and sucrose concentrations

Under aseptic conditions, leaves and roots of $L$. artemisiifolia plantlets were removed. The 144 stem segments were excised at approximately
$10 \mathrm{~mm}$ in length, containing two axillary buds. They were inoculated in $200 \mathrm{ml}$ flasks containing MS medium supplemented with $7 \%$ agar $(\mathrm{w} / \mathrm{v})$ and their respective treatments, which consisted of different concentrations of MS medium macronutrients (Murashige \& Skoog 1962) [25\% (1/4 MS - MS basal medium with macronutrients at quarter strength); $50 \%$ (1/2 MS, MS basal medium with macronutrients at half strength); and $100 \%$ (MS basal medium with macronutrients at full strength) $(\mathrm{w} / \mathrm{v})]$, combined at different sucrose concentrations $(0.00 \mathrm{mM} ; 0.34 \mathrm{mM} ; 0.68 \mathrm{mM}$ and $1.03 \mathrm{mM}$ ). The in vitro cultures were kept in a growth room under the same conditions as the previous item.

The evaluation was carried out after 60 days of cultivation. Under aseptic conditions, the shoots were removed from the flasks and washed in distilled and autoclaved water. The following were evaluated: shoot height; number of shoots and number of leaves. The experimental design was completely randomized, in $3 \times 4$ factorial design (three levels of macronutrient concentration $\times$ four sucrose levels), resulting in twelve treatments and thirty replications (per treatment). One experimental unit consisted of one bottle containing one nodal segment.

\section{Light-Emitting Diodes on shoot proliferation and rooting \\ Under aseptic conditions, the leaves, shoot} apex and roots of the explants were removed. Nodal segments measuring $10 \mathrm{~mm}$ were inoculated in MS culture medium ( $25 \%$ macronutrients) and their respective treatments, characterized by different light conditions: $100 \%$ blue; (455 nm); $100 \%$ red $(660 \mathrm{~nm}) ; 70 \%$ red $+30 \%$ blue; $70 \%$ blue $+30 \%$ red; and control with white fluorescent light bulb (Osram ${ }^{\circledR}$ brand, $\left.25 \mu \mathrm{mol} \cdot \mathrm{m}^{-2} \cdot \mathrm{s}^{-1}\right)$. The Tecnal ${ }^{\circledR}$ LED system was used, which consists of four LED row shelves (196 red and 196 blue), containing a panel with photoperiod control. The explants were grown in growth room under the same conditions as the previous item. After 45 days, the shoots formed were evaluated, observing shoot height, number of shoots and presence or absence of roots. The experimental design was completely randomized with five treatments and twenty replicates.

\section{Pigment contents}

Quantification of chlorophyll and carotenoid content in relation to different sucrose and 
macronutrient levels of the MS medium was done using the Lichtenthaler protocol (Lichtenthaler 1987). The experiment was performed in triplicate. Thus, $150 \mathrm{mg}$ of leaves from each treatment of the previous item were fragmented. Then, they were transferred into 2-mL plastic micro-tubes and addition of $1.5 \mathrm{~mL}$ of acetone. The microtubes were kept on a rotary shaker for $24 \mathrm{~h}$ at low temperature $\left(8^{\circ} \mathrm{C}\right)$. After that, the cetonic solutions were removed and their absorbance was determined through a spectrophotometer. Calculations of the concentrations of chlorophyll a $(\mathrm{Ca})$, chlorophyll $\mathrm{b}(\mathrm{Cb})$ and carotenoids $(\mathrm{C})$ were performed and expressed in $\mu \mathrm{g}$ per $\mathrm{ml}$ extract.

\section{Statistical analysis}

Data were submitted to analysis of variance (Anova), and the means submitted to Tukey test with 95\% probability. Data that did not meet Anova's assumptions were submitted to Box-Cox transformation. The program used for data analysis was Minitab (Minitab 2010) and GraphPad Prism (Radushev 2007) was used for the graphs.

\section{Results and Discussion}

Influence of different macronutrient and sucrose concentrations

Treatment with $50 \%$ of macronutrient concentration associated with $0.34 \mathrm{mM}$ sucrose obtained the highest mean in shoot height (20.53 mm) (Fig. 1a) compared to 100\% MS macronutrients combined with $1.03 \mathrm{mM}$ sucrose, corresponding to an increase of $351.21 \%$ (Tab. 1 ). In relation to number of shoots and number of leaves, the treatment with $25 \%$ macronutrients combined with $0.00 \mathrm{mM}$ sucrose promoted an increase of 220,61\% and 152,09\% (respectively) in relation to $100 \% \mathrm{MS}$ macronutrients combined with $1.03 \mathrm{mM}$ sucrose (Fig. 1b). We observed that the treatment with $100 \%$ macronutrients combined with $1.03 \mathrm{mM}$ sucrose obtained the lowest averages, therefore, suggesting a likely toxicity due to excess of salts in the culture medium. Further studies should be performed to confirm such a toxicity relationship.

The development of cells and tissues in in vitro plant culture requires balancing between PGRs, organic substances and mineral nutrients. In a study involving Dendranthema grandiflora Tzevele cv. Rage (Asteraceae) the concentration of $75 \%$ macronutrients was ideal for the species, characterizing an increase in the number of shoots and roots in this concentration. However, the authors describe a decrease in the number of roots at $100 \%$ macronutrient concentration, which may have caused toxicity due to the high salt concentration (Borges et al. 2011).

Lower macronutrient concentrations (from $50 \%$ to $25 \%$ ) associated with low sucrose
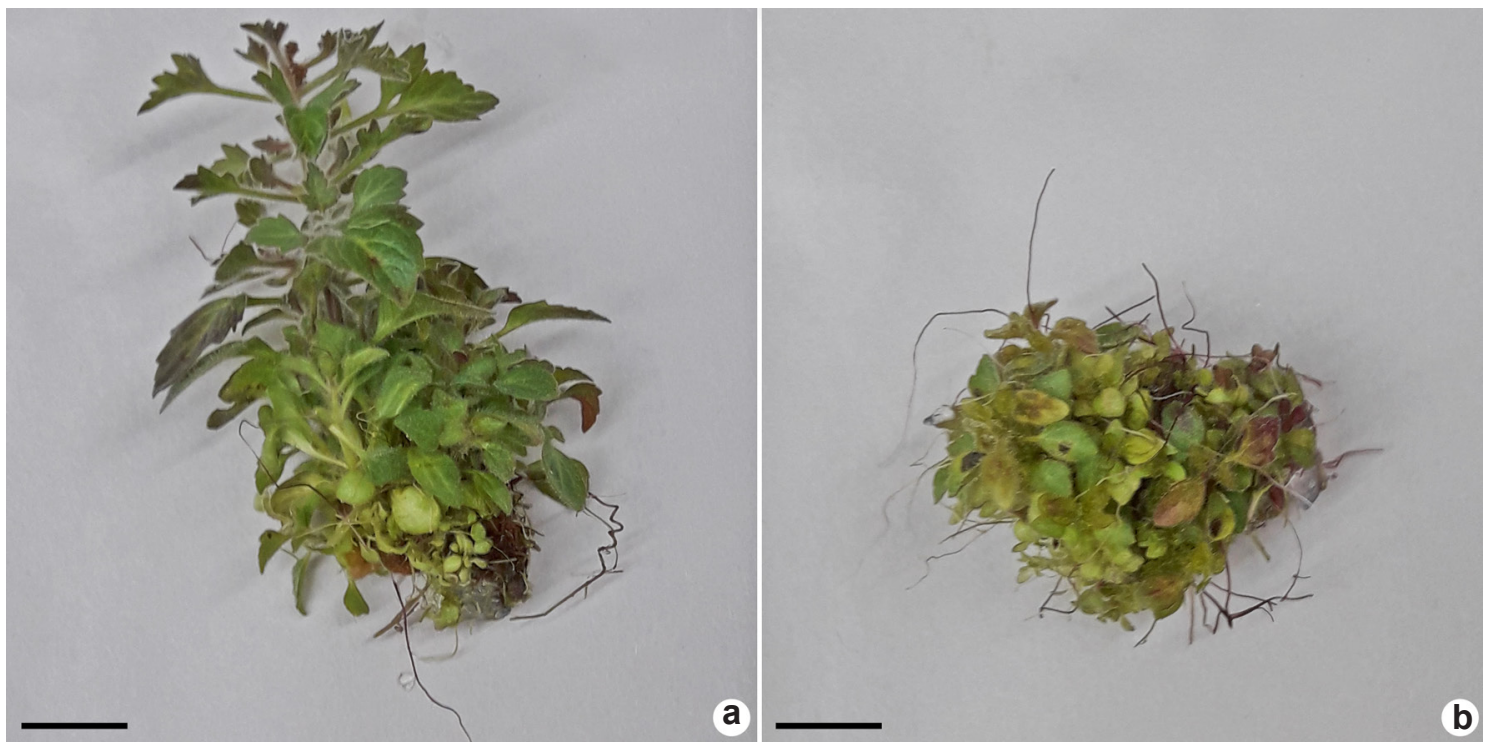

Figure 1 - a-b. Effect of different concentrations of sucrose combined with different concentrations of macronutrients on the micropropagation of Lomatozona artemisiifolia - a. $50 \%$ macronutrients $+0.34 \mathrm{mM}$ sucrose; b. $25 \%$ macronutrients and no sucrose. Scale bar $=60 \mathrm{~mm}$. 
Table 1 - Means of the variables analyzed for Lomatozona artemisiifolia micropropagation in relation to the percentage of MS medium macronutrients combined with different sucrose concentrations in the MS medium.

\begin{tabular}{ccccc}
\hline Macro MS (\%) & Sucrose $(\mathbf{m M})$ & Height $(\mathbf{m m})$ & Shoots & Leaves \\
\hline 25 & 0 & $11.47 \mathrm{abc}$ & $4.2 \mathrm{a}$ & $11.47 \mathrm{a}$ \\
25 & 1 & $11.8 \mathrm{abc}$ & $3.77 \mathrm{ab}$ & $11.8 \mathrm{ab}$ \\
25 & 2 & $14.55 \mathrm{abc}$ & $2.93 \mathrm{abc}$ & $14.55 \mathrm{bcd}$ \\
25 & 3 & $14.38 \mathrm{ab}$ & $2.14 \mathrm{abc}$ & $14.38 \mathrm{bcd}$ \\
50 & 0 & $10.13 \mathrm{abcd}$ & $2.23 \mathrm{abc}$ & $10.13 \mathrm{bcd}$ \\
50 & 1 & $20.53 \mathrm{a}$ & $3.13 \mathrm{ab}$ & $20.53 \mathrm{abc}$ \\
50 & 2 & $12.26 \mathrm{abc}$ & $3.13 \mathrm{ab}$ & $12.26 \mathrm{bc}$ \\
50 & 3 & $6.65 \mathrm{~cd}$ & $1.72 \mathrm{~cd}$ & $6.65 \mathrm{de}$ \\
100 & 0 & $7.07 \mathrm{bcd}$ & $2.97 \mathrm{abc}$ & $7.07 \mathrm{bcd}$ \\
100 & 1 & $8.27 \mathrm{bcd}$ & $3.23 \mathrm{abc}$ & $8.27 \mathrm{bc}$ \\
100 & 2 & $9.48 \mathrm{bcd}$ & $2.35 \mathrm{bcd}$ & $9.48 \mathrm{~cd}$ \\
100 & 3 & $4.55 \mathrm{~d}$ & $1.31 \mathrm{~d}$ & $4.55 \mathrm{e}$ \\
\hline
\end{tabular}

* Means that do not share a letter are significantly different by the test of Tukey with $95 \%$ probability.

concentrations (from $0.00 \mathrm{mM}$ to $0.68 \mathrm{mM}$ ) produced better results for the variables analyzed for L. artemisiifolia propagation (Fig. 2). Probably, this relationship is explained by the fact that plant communities that grow in rupestrian field environments have lower nutritional requirements than plants that live in fertile soil environments (Oliveira et al. 2015).

Rupestrian fields are known for their nutrient-poor soils, and despite their recognition as a global biodiversity hotspot, little is known about the diversity of phosphorus acquisition strategies and other aspects of plant mineral nutrition in this region (Oliveira et al. 2015). These plants have specialized roots that act on nutrient absorption. The roots secrete acidic substances (for example, carboxylates), which degrade the rock to which they are attached, and thus obtain necessary macronutrients for their nutrition, such as phosphorus (Teodoro et al. 2019). Therefore, further studies involving this macronutrient may be carried out to clarify the relationship between L. artemisiifolia and phosphorus.

A significant increase was found in shoot proliferation when sucrose was not used (Fig. 2). Carbon is known to act in the culture medium as a way of supplying the plant for energy needs (Durand et al. 2016). However, as stated earlier, $L$. artemisiifolia is a species that grows in rupestrian field environments, which have nutrient scarcity (Oliveira et al. 2015).
Although this experiment had been developed in natural ventilation system (Saldanha et al. 2012), combined with fluorescent white light, probably, plants have approached a condition similar to photoautotrophic, in which the plant can produce energy using the available light source without the addition of an external carbon source (Nguyen et al. 2016).

White fluorescent lights have continuous spectrum (Lister et al. 2004), over which shiny lines overlap. These are caused by mercury and phosphorus vapor, which generates emission peaks at $450 \mathrm{~nm}$ and $550 \mathrm{~nm}$. (Onorato et al. 2016). For many species, this luminous condition is sufficient for shoot proliferation, as in sugarcane (Silva et al. 2016). Thus, further studies should be performed using bioreactors to confirm the photoautotrophic condition in fluorescent light.

The treatment corresponding to $25 \%$ macronutrients combined with $0.00 \mathrm{mM}$ sucrose achieved higher means for number of leaves (Tab. 1). This variation occurred probably since L. artemisiifolia is considered an undomesticated allogamous species, which explains the wide variation. Thus, the relationship between macronutrients, sucrose and number of leaves of L. artemisiifolia should be further investigated. In a study involving Gerbera hybrida (Asteraceae), the number of leaves was also affected by the excess of macronutrients, especially the $\mathrm{NH}_{4}^{+} \mathrm{K}^{+}$ ions (Niedz et al. 2014). 

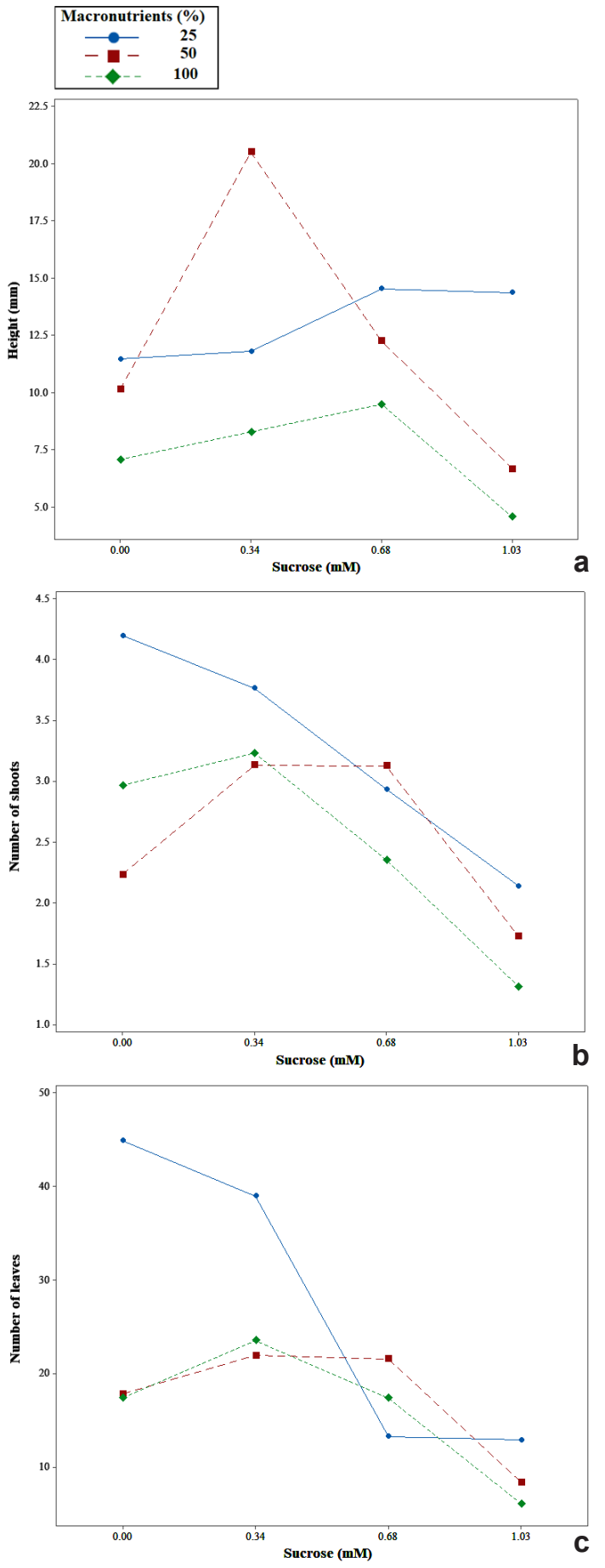

Figure 2 - a-c. Lomatozona artemisiifolia propagation in relation to different levels of the MS medium macronutrients combined with different sucrose levels - a. height of the shoots; b. number of shoots; c. number of leaves.
Light-Emitting Diodes on shoot proliferation and rooting

Higher percentages of red LEDs $(100 \%$ red and $70 \%$ red $+30 \%$ blue) resulted in higher shoot height, with averages of $37.5 \mathrm{~mm}$ and $37.43 \mathrm{~mm}$ respectively. $100 \%$ red light also provided more plants with roots, with $100 \%$ rooted plantlets; however, there was no significant difference between the number of shoots and the evaluated light condition (Fig. 3). 100\% of the rooted plantlets of $L$. artemisiifolia survived after acclimatization, which was carried out using vermiculite substrate, in a greenhouse with controlled temperature, irrigation and humidity $\left[27^{\circ} \mathrm{C} \pm 2\right.$, sprinkling for 5 min ( 3 times a day) and $70 \%$ humidity].

Red light plays a fundamental role in modulating plant morphogenetic responses. This relationship occurs in various ways, among which, stretching of the hypocotyl and facilitation of rooting (Demotes-Mainard et al. 2016). The formation of roots under red light irradiation occurs through the action of phytochromes, which are found in the leaf and modulate the morphogenetic responses through the capture of red or far-red light (Smith 2000). In Calendula officinalis L. (Asteraceae), the red-light led to an early flowering and improved growth compared with white lightgrown plants. In addition, the pigment content has increased considerably (Aliniaeifard et al. 2018). Thus, further studies may be carried out to confirm the potential for increased chlorophyll under LED irradiance.

Lower means of plant height and number of rooted plants were observed when $100 \%$ blue light were used. The wavelength of blue light is responsible for the activation of cryptochromes (Pedmale et al. 2016). In Arabidopsis, blue light plays a key role in inhibiting etiolation of hypocotyl by influencing the expression of genes linked to the production of auxins and gibberellins. Thus, plants gain short height and consequently rooting is impaired by inhibition of auxins (Folta et al. 2003). However, further studies may be conducted to prove the relationship between blue light and chlorophyll production in L. artemisiifolia.

No difference was observed between light conditions and number of shoots. However, this relationship was determined in this work when we found a high shoot proliferation with low percentages of macronutrients and sucrose levels. Also, in the shoot proliferation of Campomanesia rufa (Berg) Niedenzu, the red and blue LED 

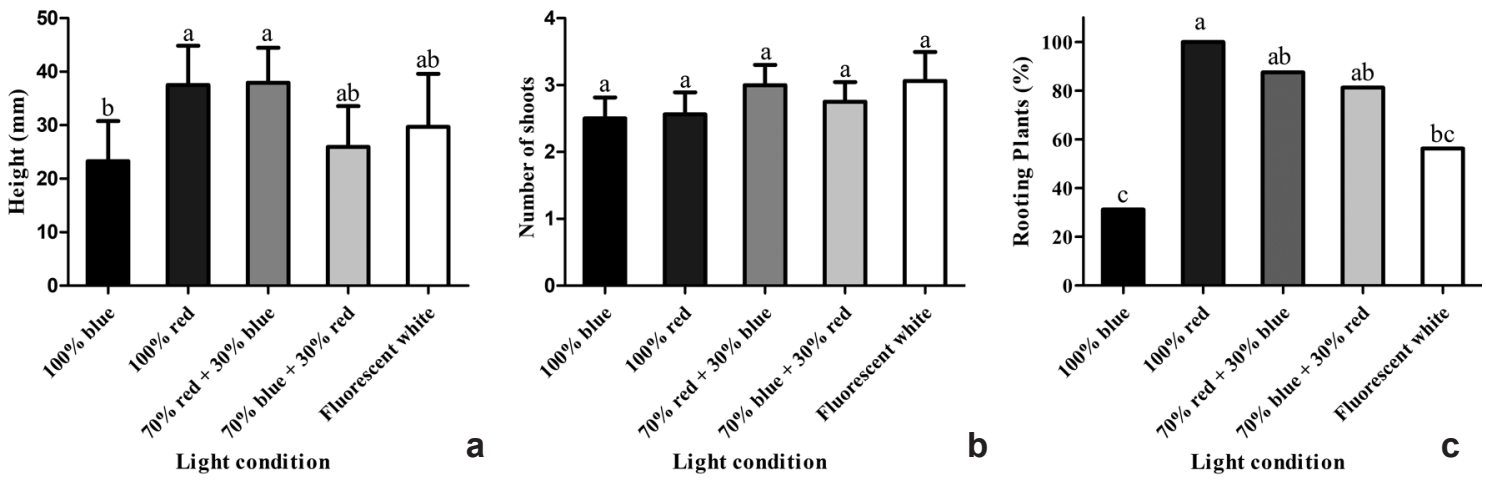

Figure 3 - a-c. Response of Lomatozona artemiziifolia to the different light conditions - a. height of plants; b. number of shoots; c. percentage of rooted plants. Bars represent the respective standard errors.
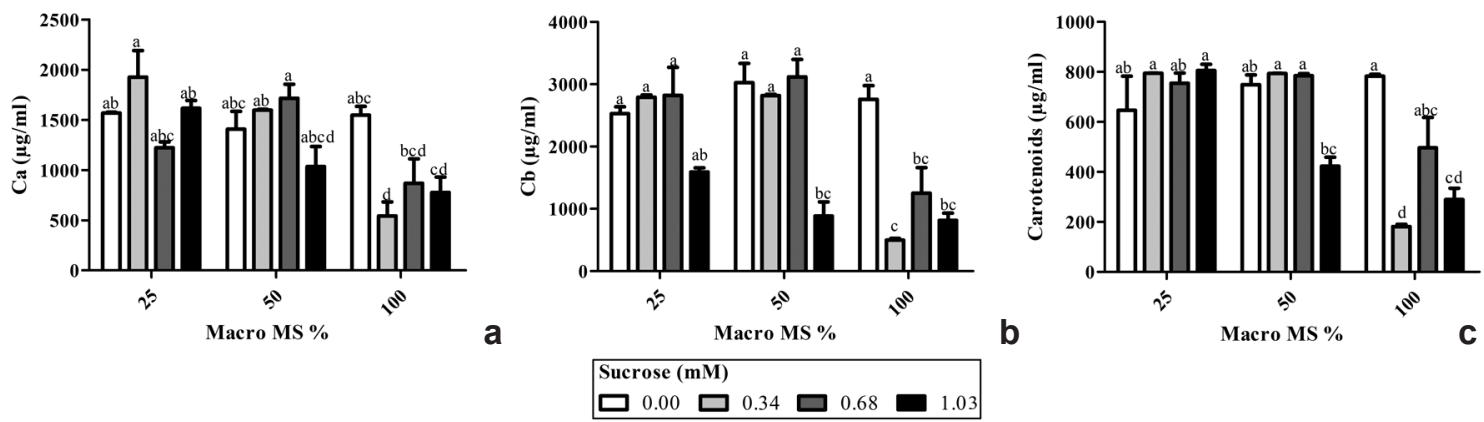

Figure 4 -a-c. Production of chlorophyll $a$ (a), $b$ (b) and carotenoids (c) in Lomatozona artemisiifolia micropropagation using different percentages of macronutrients in MS medium combined with different sucrose levels in culture medium. Bars represent the respective standard errors.

light combinations did not differ from the control (conventional white light) (Sant'Ana et al. 2018). On the other hand, other studies demonstrate that blue light may act as a cytokine-like growth regulator, inhibiting hypocotyl growth and increasing shoot proliferation (Vandenbussche et al. 2007; Pedmale et al. 2016). In addition, blue light may also produce distinct results in combination with plant growth regulators found in the culture medium (Vandenbussche et al. 2007). For this reason, further studies should be conducted using new blue light combinations associated with plant growth regulators to evidence this relationship.

\section{Pigments contents}

The best treatments for chlorophyll $a$ production were $25 \%$ macronutrients combined with $0.34 \mathrm{mM}$ sucrose and $50 \%$ macronutrients combined with $0.68 \mathrm{mM}$ sucrose (Fig. 4). In general, higher sucrose levels associated with high macronutrient levels were detrimental to pigment production, including carotenoids, in which a decrease in production was observed in treatments with 100\% macronutrients (Fig. 4). In a study carried out with Calendula officinalis L., it was observed that in vitro carotenoid production was optimized by modifying the concentration of macronutrients in the culture medium and enhancing to sucrose concentration (Legha et al. 2012).

In relation to plant tissue culture, the most commonly used carbon source in MS medium is sucrose at a concentration of $3 \%$ (1.02 mM) (Shahzad et al. 2017). In a study with Chrysanthemum leiophyllum (Asteraceae), the authors found that the excess of salts promoted a decrease in the number of shoots, as well as in the other growth characteristics (Kuritskaya et al. 2016).

Proliferation of Lomatozona artemisiifolia shoots was successfully performed using MS 
culture medium with $25 \%$ macronutrients combined with $0.00 \mathrm{mM}$ sucrose, with an average of 4 shoots per explant.

The decrease in Macronutrient and sucrose concentrations influenced positively the pigment contents and concentrations of $100 \%$ macronutrients and the increase of sucrose level impaired their production.

The best rooting condition for L. artemisiifolia shoots was under $100 \%$ red LED, which promoted $100 \%$ rooted shoots. High percentages of red lights promoted higher plantlets. However, the different light conditions did not influence the shoot proliferation.

\section{Acknowledgements}

The authors would like to thank CAPES and $\mathrm{CNPq}$, for funding the research.

\section{References}

Abraham J \& Thomas DT (2018) Recent advances in Asteraceae tissue culture. In: Anis M \& Ahmad N (eds.) Plant tissue culture propagation, conservation crop improvement. Springer, Singapure. Pp. 161-195.

Aliniaeifard S, Seif M, Arab M, Zare Mehrjerdi M, Li T \& Lastochkina O (2018) Growth and photosynthetic performance of Calendula officinalis under monochromatic red light. International Jounal of Horticultural Sciece and Technology 5: 123-132.

Almeida GSS, Carvalho-Okano RM, Nakajima JN \& Garcia FCP (2014) Asteraceae Dumort nos campos rupestres do Parque Estadual do Itacolomi, Minas Gerais, Brasil: Barnadesieae e Mutisieae. Rodriguesia 65: 311-328.

Angela C, Marcella B, Salvatore P, Giuseppe G, Ornella B, Caterina C, Francesco C \& Maurizio S (2016) In-vitro regeneration of Calendula maritima guss. (asteraceae), a threatened plant endemic to western sicily. Pakistan Journal of Botany 48: 589-593.

Borges DI, Oliveira MC, Penoni ES, Pádua TRP, Braga FT \& Pasqual M (2011) Micropropagation of chrysanthemum (Dendranthema grandiflora Tzevele Cv. Rage) Under natural and artificial light in different concentration of the culture media. Plant Cell Culture and Micropropagation 7: 9-16.

Brandão RJA, Castilho CJM \& Morais HA(2017) Modern agriculture in the Cerrado Biome: continuing the disrespect of nature. Journal of Hyperspectral Remote Sensing 7: 134-149.

Briggs WR \& Olney MA (2001) Photoreceptors in plant photomorphogenesis to date. Five phytochromes, two cryptochromes, one phototropin, and one superchrome. Plant Physiology 125: 85-88.

Butt SJ, Varis S, Nasir IA, Sheraz S \& Shahid A (2015) Micro propagation in advanced vegetable production: a review. Advances in Life Science 2: 48-57.

CNCFlora - Centro Nacional de Conservação da Flora (2012) Lomatozona artemisiifolia in Lista Vermelha da flora brasileira versão 2012.2. Available at $<$ http://cncflora.jbrj.gov.br/portal/pt-br/profile/ Lomatozona artemisiifolia $>$. Access on 12 January 2019.

Demotes-Mainard S, Peron T, Corot A, Bertheloot J, Le Gourrierec J, Pelleschi-Travier S, Crespel L, Morel P, Huche-Thelier L, Boumaza R, Vian A, Guerin V, Leduc N \& Sakr S (2016) Plant responses to red and far-red lights, applications in horticulture. Environment Experimental Botany 121: 4-21.

Durand M, Porcheron B, Hennion N, Maurousset L, Lemoine R \& Pourtau N (2016) Water deficit enhances $\mathrm{C}$ export to the roots in Arabidopsis Thaliana plants with contribution of sucrose transporters in both shoot and roots. Plant Physiology 170: 1460-1479.

Espinosa-Leal CA, Puente-Garza CA \& García-Lara S (2018) In vitro plant tissue culture: means for production of biological active compounds. Planta 248: 1-18.

Faria RT, Rodrigues FN, Oliveira LVR \& Müller C (2004) In vitro Dendrobium nobile plant growth and rooting in different sucrose concentrations. Horticultura Brasileira 22: 780-783.

Folta KM \& Childers KS (2008) Light as a growth regulator: controlling plant biology with narrowbandwidth solid-state lighting systems. HortScience 43: 1957-1964.

Folta KM, Pontin MA, Karlin-Neumann G, Bottini R \& Spalding EP (2003) Genomic and physiological studies of early cryptochrome 1 action demonstrate roles for auxin and gibberellin in the control of hypocotyl growth by blue light. Plant Jounal 36: 203-214.

Gupta SD \& Jatothu B (2013) Fundamentals and applications of light-emitting diodes (LEDs) in in vitro plant growth and morphogenesis. Plant Biotechnol Reports 7: 211-220.

Kodym A, Senula A, Temsch EM, Hood-Nowotny R, Schumacher F, Sekurova ON, Zotchev SB \& Kiehn M (2018) Micropropagation and cryoconservation of the endangered plant species Artemisia laciniata (asteraceae). Cryo-Letters 39: 177-189.

Kuritskaya EV, Nedoluzhko AI, Vrzhosek EV \& Boltenkov EV (2016) Micropropagation of Chrysanthemum leiophyllum (Asteraceae). Turczaninowia 19: 99-104.

Legha MR, Prasad KV, Singh SK, Kaur C, Arora A \& Kumar S (2012) Induction of carotenoid pigments in callus cultures of Calendula officinalis L. in response to nitrogen and sucrose levels. In Vitro Cellular and Developmental Biology - Plants 48: 99-106. 
Lichtenthaler HK (1987) Chlorophylls and carotenoids: pigments of photosynthetic biomembranes. In: Methods Enzymol. Academic Press, New York. Pp. 350-382.

Lister GG, Lawler JE, Lapatovich WP \& Godyak VA (2004) The physics of discharge lamps. Reviews of Modern Physics 76: 541-598.

Martinelli G, Messina T \& Santos Filho L (2014) Livro Vermelho da Flora do Brasil - Plantas Raras do Cerrado. CNCFlora, Rio de Janeiro. Available at $<$ http://dspace.jbrj.gov.br/jspui/handle/doc/27>. Access on 20 February 2019.

Martinelli G \& Moraes M (2013) Livro Vermelho da Flora do Brasil. Centro Nacional de Conservação da Flora, Rio de Janeiro. 1100p.

Massa GD, Kim HH, Wheeler RM \& Mitchell CA (2008) Plant productivity in response to LED lighting. HortScience 43: 1951-1956.

Massaro R, Fadin DA, Pedroso-de-Moraes C, Vieira AS \& Marteline MA (2018) Light quality in vitro growth and acclimatization of two varieties of Phalaenopsis amabilis alba Blume (Orchidaceae). Iheringia - Série Botânica 73: 208-215.

Minitab (2010) MINITAB: statistical software. Version 18. Minitab, Inc. State College. Available at $<$ https://www.minitab.com/en-us/support/ downloads/ $>$.

Moreira MP (2018) Lomatozona artemisiifolia Baker: micropropagação, fitoquímica e atividade inseticida no controle de Bemisia tabaci. Dissertação de Mestrado. Universidade Federal de Goiás, Goiânia. $77 \mathrm{p}$.

Murashige T \& Skoog F (1962) A revised medium for rapid growth and bioassays with tobacco tissue cultures. Physiologia Plantarum 15: 473-497.

Nakajima JN, Junqueira TV, Freitas FS \& Teles AM (2012) Comparative analysis of red lists of the Brazilian flora: Asteraceae. Rodriguesia 63: 39-54.

Nguyen QT, Xiao Y \& Kozai T (2016) Photoautotrophic micropropagation. In: Kozai T, Niu G \& Takagaki M (eds.) Plant factory: an indoor vertical farming system for efficient quality food production. Academic Press, Elsevier, San Diego. Pp. 271-283.

Niedz RP, Hyndman SE, Evens TJ \& Weathersbee AA (2014) Mineral nutrition and in vitro growth of Gerbera hybrida (Asteraceae). In Vitro Cellular and Developmental Biology. Plants 50: 458-470.

Nisa ZU (2018) Micropropagation through apical shoot explants and morphogenic potential of different explants of Saussurea lappa: an endangered medicinal plant. Pure Applied Biology 8: 585-592.

Oliveira RS, Galvão HC, Campos MCR, Eller CB, Pearse SJ \& Lambers H (2015) Mineral nutrition of campos rupestres plant species on contrasting nutrient-impoverished soil types. New Phytololgist 205: 1183-1194.

Onorato P, Gratton L, Malgieri M \& Oss S (2016) The photoluminescence of a fluorescent lamp: didactic experiments on the exponential decay. Physics Education 52: 015011.

Paiva Neto VB \& Otoni WC (2003) Carbon sources and their osmotic potential in plant tissue culture: does it matter? Science Horticulturae (Amsterdam) 97: 193-202.

Pedmale UV, Huang SSC, Zander M, Cole BJ, Hetzel J, Ljung K, Reis PAB, Sridevi P, Nito K \& Nery JR (2016) Cryptochromes interact directly with PIFs to control plant growth in limiting blue light. Cell 164: 233-245.

Pereira-Netto AB (2001) Effect of inhibitors of ethylene biosynthesis and signal transduction pathway on the multiplication of in vitro-grown Hancornia speciosa. Plant Cell, Tissue and Organ Culture 66: $1-7$.

Saldanha CW, Otoni CG, Azevedo JLF, Dias LLC, Rêgo MM \& Otoni WC (2012) A low-cost alternative membrane system that promotes growth in nodal cultures of Brazilian ginseng [Pfaffia glomerata (Spreng.) Pedersen]. Plant Cell Tissue and Organ Culture 110: 413-422.

Sant'Ana CRO, Paiva R, Reis MV, Silva DPC \& Silva LC (2018) In vitro propagation of Campomanesia rufa: an endangered fruit species. Ciencia e Agrotecnologia 42: 372-380.

Shahzad A, Sharma S, Parveen S, Saeed T, Shaheen A, Akhtar R, Yadav V, Upadhyay A \& Ahmad Z (2017) Historical perspective and basic principles of plant tissue culture. In: Abdin M, Kiran U \& Kamaluddin AA (eds.) Plant Biotechnology Principles and Application. Springer, Singapure. Pp. 1-36.

Silva MMA, Oliveira ALB, Oliveira-Filho RA, Camara T, Willadino L \& Gouveia-Neto A (2016) The effect of spectral light quality on in vitro culture of sugarcane. Acta Scientiarum 38: 157-161.

Smith H (2000) Phytochromes and light signal perception by plants - an emerging synthesis. Nature 407: 585-591.

Sorace M, Faria RT, Damasceno CV, Gomes GP, Barbosa CM, Vieira FGN, Silva GL, Takahashi LSA \& Schnitzer JA (2008) In vitro growth of Oncidium baueri (Orchidaceae) at different macronutrients and sucrose concentrations. Semina: Ciências Agrarárias 29: 775-781.

Stutte GW (2009) Light-emitting diodes for manipulating the phytochrome apparatus. HortScience 44: 231234.

Teodoro GS, Lambers H, Nascimento DL, Britto Costa P, Flores-Borges DNA, Abrahão A, Mayer JLS, Sawaya ACHF, Ladeira FSB, Abdala DB, Pérez CA \& Oliveira RS (2019) Specialized roots of Velloziaceae weather quartzite rock while mobilizing phosphorus using carboxylates. Functional Ecology 33: 762-773.

Terrer C \& Tomás F (2001) Determination of 
macronutrients to be included in in vitro culture media according to leaf concentrations. Jounal of Horticultural Science and Biotechnology 76: 484-488.

Trindade LMP, Fernandes YS \& Almeida Gonçalvescia L (2014) Diversidade e desenvolvimento dos tricomas glandulares de Lomatozona artemisiifolia Baker (Asteraceae - Eupatorieae) - uma planta endêmica do Cerrado de Goiás. Iheringia - Série Botânica 69: 235-243.
Vandenbussche F, Habricot Y, Condiff AS, Maldiney R, Straeten DVD \& Ahmad M (2007) HY5 is a point of convergence between cryptochrome and cytokinin signalling pathways in Arabidopsis thaliana. Plant Journal 49: 428-441.

Yeh N \& Chung JP (2009) High-brightness LEDs energy efficient lighting sources and their potential in indoor plant cultivation. Renewable and Sustainable Energy Reviews 13: 2175-2180. 